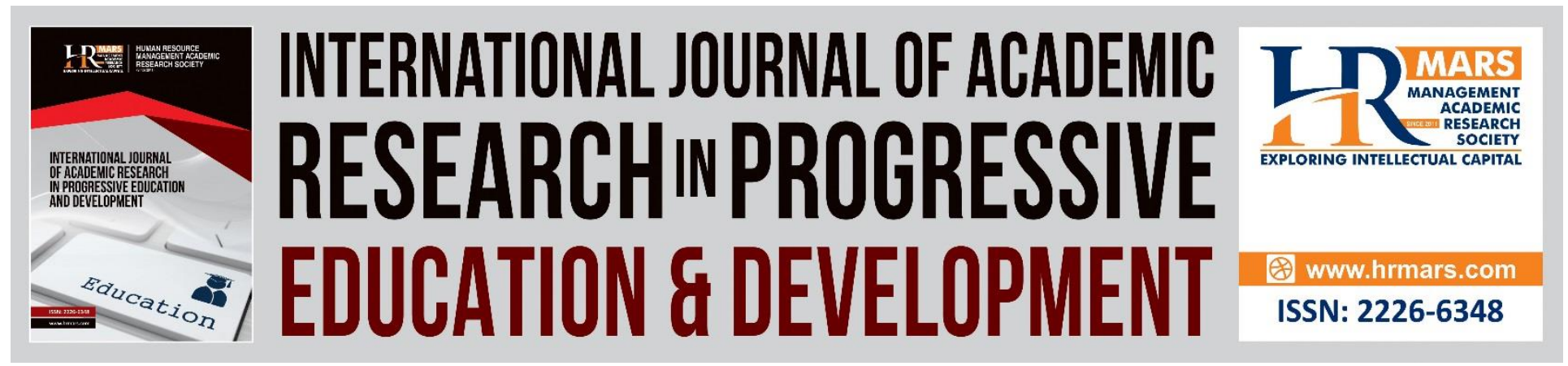

\title{
Effects of Open Innovation Towards School Performance in Johore State
}

Tamil Selvi Rajoo, Mohd Khairuddin Ramliy, Sabrinah Adam, Beni Widarman Yus Kelana

To Link this Article: http://dx.doi.org/10.6007/IJARPED/v10-i1/9227

DOI:10.6007/IJARPED/v10-i1/9227

Received: 25 December 2020, Revised: 28 January 2021, Accepted: 10 February 2021

Published Online: 26 February 2021

In-Text Citation: (Rajoo et al., 2021)

To Cite this Article: Rajoo, T. S., Ramliy, M. K., Adam, S., \& Kelana, B. W. Y. (2021). Effects of Open Innovation Towards School Performance in Johore State. International Journal of Academic Research in Business and Social Sciences, 10(1), 522-535.

Copyright: (C) 2021 The Author(s)

Published by Human Resource Management Academic Research Society (www.hrmars.com)

This article is published under the Creative Commons Attribution (CC BY 4.0) license. Anyone may reproduce, distribute, translate and create derivative works of this article (for both commercial and non-commercial purposes), subject to full attribution to the original publication and authors. The full terms of this license may be seen at: http://creativecommons.org/licences/by/4.0/legalcode

Vol. 10(1) 2021, Pg. 522 - 535

http://hrmars.com/index.php/pages/detail/IJARPED

JOURNAL HOMEPAGE

Full Terms \& Conditions of access and use can be found at http://hrmars.com/index.php/pages/detail/publication-ethics 


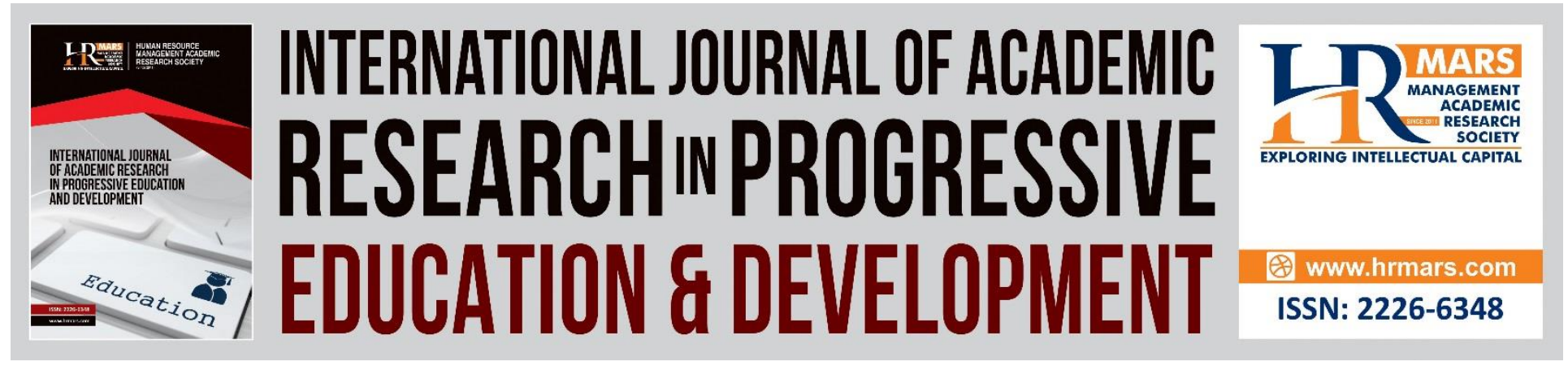

\title{
Effects of Open Innovation Towards School Performance in Johore State
}

\section{Tamil Selvi Rajoo, Mohd Khairuddin Ramliy, Sabrinah Adam, Beni Widarman Yus Kelana}

Azman Hashim International Business School, Universiti Teknologi Malaysia (UTM), Malaysia.

Email: tselvi3@utm.my,mohdkhairuddin@utm.my, sabrinah@utm.my, beni@utm.my

\begin{abstract}
Open Innovation remains the process of enabling inflow and outflow of knowledge, ideas, design, plus technologies throughout the organization during the various stages of the innovation process. This Innovation consists of inbound and outbound open innovations, whereby inbound open Innovation is the influx of knowledge, while outbound open innovation remains the outward flow of knowledge. Previously, studies related to open innovation have only focused specifically on the business world, the industrial sector while less focused on strategy and its implementation in the education sector. This study aims to fill this gap by studying open innovation in ordinary day secondary schools due to their significant contribution to development Malaysian education. Based on an open innovation model and a theory of views based on resources, this study will analyse the role of open and innovative innovation activities government support in determining the innovative capabilities of secondary schools. In this conceptual paper, the author develops the conceptual model that will be used in further research activities in education sector and will contribute to a better understanding of open innovation activities and their practices in secondary schools in Malaysia.
\end{abstract}

Keywords: Open Innovation, School performance, Innovation in School

\section{Introduction}

Open innovation, is based on the belief that knowledgeable and creative individuals outside the company can also contribute to achieving strategic goals and that sharing intellectual property both ways is useful for different parties in different ways (Jennex, et al., 2020). The more information is gained, the more educated the decisions ultimately are. The open innovation funnel on the right is more like a hybrid between a sieve and a funnel, as the development process is not limited to individuals within the facilitating company (Tiwari et al., 2020). In addition, the amount of ideas is also higher. 
Innovation can bring the use of advanced technology in schools and is able to improve school performance in stages (Horn, 2020). Furthermore, innovation is able to change the norms of learning apart from outside the school (Bogers \& Moedas, 2018). Recently, open innovation has been practiced in various learning institutions. However, previous studies show that it has not been fully applied in school norms. Thus, the implications of open innovation on school achievement have not been fully seen. In this approach, researchers take this into account and want to make a study between open innovation and the relationship with school performance.

\section{Problem Statement}

There are issues in three areas which are categorised as practical, theoretical and methodological issues in this topic.

Firstly, in practical issue, as the world battles with Covid-19 pandemic, education institution is also affected by the outbreak. The announcement of the Movement Control Order (MCO) by the Prime Minister required all educational institutions starting from preschool to tertiary level to close with immediate effect, causing learning process in classroom to halt. However, this pandemic provides an opportunity for innovation in education where learning institutions are encouraged to explore the variations of long-distance learning platforms to ensure students are still able to learn at home. Google Classroom is one of the top applications for e-learning used in Malaysia as of today. Online learning thus is an effective method of learning during pandemic. It provides the platform for teachers and educators to expand their creativity in finding the most suitable medium to execute distance learning (Bogers et al., 2019).

On the practical part, open innovation has largely covered the industrial sector in recent times and has brought performance increased (Jennex, Smolnik et al., 2020). At the same time, open innovation comprising knowledge, collaboration and outsourcing has proven to be practiced in the organization and has improved its performance. (Mamonov and Peterson 2020). At the same time, open innovation has proven to be practiced in firms and has improved workers performance (Bratton and Boak, 2020). But till now there is no studies have been taken regarding open innovation and school performances. So, researcher feel to conduct this study continues with open innovation in schools.

In addition, the education sector is among the sectors with the highest levels of Innovation. It has implemented open Innovation by increasing participation in technology, engineering, science, and mathematics disciplines relevant to technological Innovation for the learners (Osma at al., 2019). With open Innovation, there has been an increase in varied education alternatives, and states overseas are working worldwide to remain relevant by increasing their innovative capacity. For example, the states are rooting for teacher education. They are equipped to do better and teacher collaboration to enhance content distribution, content curation, and virtual association to build trust and progress an innovative environment (Yun \& Yigitcanlar, 2018). Other key areas that the education sector has kept innovating include design thinking, assessment models, and learners' voice recognition.

Moreover, through open Innovation, education institutions have been able to transform learning and teaching practices in schools. Integrating news types of innovations such as digital technologies has filled up gaps in both the teachers' and learners' digital skills and provided highquality digital learning resources and software (Yun \& Yigitcanlar, 2018). Innovative pedagogic 
models such as real-time assessment, online laboratories, and gaming have indicated improved thinking capability and enhanced learners' creativity, imagination, and problem-solving skills (Becker et al, 2018). The virtual laboratories have been productive and cut down the cost of practical experiments by creating a virtual experiential learning technique.

It has overcome geographical barriers by enhancing collaboration with overseas nations. Through cooperation, the learners can have a vision into other cultures and experience multiethnic communication and copy the environment of today's specialized settings (Yun \& Yigitcanlar, 2018). This kind of collaboration has provided new plus accurate skills and open work experiences for everyone to participate. Also, through the implementation of Innovation through the education sector has helped create like-minded people, and together with greater things and opportunities have been developed (Bogers \& Moedas, 2018). For instance, such people form clusters, whereby together they can trial on new ways of education and instruction.

The education sector is facing the limitation of marshalling technology to broaden access and advance the quality of opportunities. In the United State, education works towards achieving universal access to innovations to its people (Vanhaverbeke \& Frattini, 2018). However, this has proved a challenge, as some learners are disadvantaged when innovations and new opportunities do not meet their needs. While digital technologies enhance education and opportunities to learn, a problem is evident as factors influencing access to the technologies are left lagging (Vanhaverbeke \& Frattini, 2018). For instance, social attitudes towards learning, connectivity to the technologies, skills plus competencies of learners, and teachers, laws associated with financial and business models are key considerations that are regularly ignored but always set a negative impact for disadvantaged learners (Sanders et.al, 2020).

Most countries are not in the routing wheel for digitization and are minimally supporting digitizing teachers. This role should not be completely left for the schools and the education sector (Bogers \& Moedas, 2018). Innovators and specialists from the management, together with business, education, and research, should labour together to advance and implement new tactics for enlightening and supporting teachers so that they are well equipped to face trials that come up as a result of digitization (Yun \& Liu, 2019). By doing so, there will be an increase in educational and informational material plus new ways of offering the material by replicating and discussing it.

In the rapid development of education today, new technologies such as innovations in education are emerging providing a variety of tools for educators to improve the $T$ \& $L$ processes. Education innovation also opens new opportunities and beginning in improving learning, transforming the delivery of knowledge, enriching creativity in the educational process and even changing the education ecosystem in Malaysia. The use of innovation has indeed given new and more effective implications in education and at the same time contributing to the smoothness of education (Horn 2020). This stream of change demands a rapid transformation in all aspects of the educational process, whether from the curriculum, communication, creativity, teaching methods, learning styles, teaching aids or teaching design using technology approaches. This statement is also agreed by (Oyekan et al. 2020) who stated that the integration of innovation in education involves the discipline of a knowledge application aimed at facilitating the teaching, learning and achievement process. 
From the literature review it can be said that a strong framework for this problem has not been built. Therefore, the author suggest it is desirable to build an appropriate framework for this problem statement. In addition, it can solve the problem statement quite effectively. At the same time, it can be used as an example to researchers who do research in this field. On the other part, past studies have shown that this open innovation can enhance the productivity of an organization. Which enables the performance of an organization and the motivation of an organization in most countries to date. Thus, this open innovation can increase the productivity of a school. Furthermore, recent studies on open innovation applications in the Education sector are lacking. In addition, a new framework will gain a new perspective on this open innovation in the Education world. Thus, the results of this study can serve as a reference to other researchers in the future. In general, it will be a good source of reference.

\section{Underpinning Model / Theories}

Innovation is a process whereby new ideas has been successfully explored and it is a mindset or an outcome which arises from innovation process of creating something (Edwards Schachter, 2018). Thus, several underpinning theories has been used in this research as well as to focus the research objectives, research questions and research gap as well. In this part, the researcher discusses about two theories which is open innovation model and resource -basedview theory and study about the phenomenon of open innovation activities in primary schools and their influence direct to the school performance.

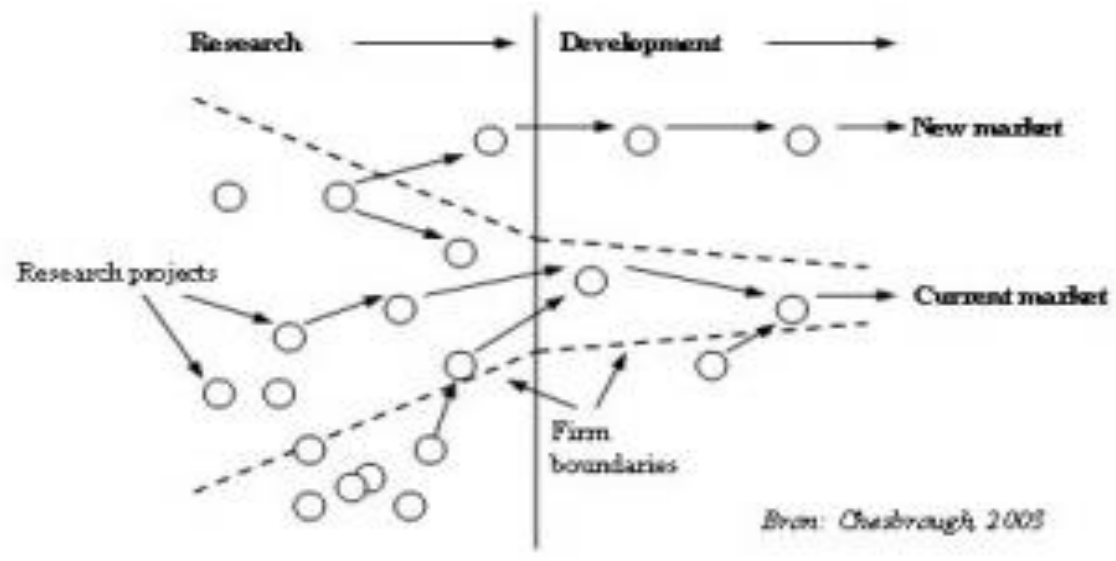

Figure 1: Open Innovation Model

Source: (Chesbrough, 2003)

This open innovation model was introduced into the business world by Chesbrough in 2003. Through this model, he has introduced new business strategies by adopting open innovation activities that include knowledge acquisition, collaboration and outsourcing activities as opposed to closed business strategies previously practiced. As such, it has given the business world a new perspective on the growth of their factory or organization. At the same time, through this model it can be seen that a business can grow from external involvement and support rather than relying on the involvement and support of its own organization. 
Vol. 10, No. 1, 2021, E-ISSN: 2226-6348 @ 2021 HRMARS

On the other part this innovation model can look further through Oslo Manual (2005) which is consist of elements in innovation.

Table 1: Innovation Model

\begin{tabular}{|c|c|c|}
\hline No & Definition of innovation & Sources \\
\hline 1. & $\begin{array}{l}\text { Is the implementation of a new or } \\
\text { significantly improved product (good } \\
\text { or service). }\end{array}$ & \multirow{8}{*}{$\begin{array}{l}\text { Adapted from } \\
\text { Oslo Manual (2005), } \\
\text { Becker et al, 2018, } \\
\text { Jugend et al,2018, } \\
\text { Linaker et al,2018, }\end{array}$} \\
\hline 2. & Process, a new marketing method & \\
\hline 3. & $\begin{array}{l}\text { A new organizational method in } \\
\text { business } \\
\text { practices, workplace organization or } \\
\text { external relations. }\end{array}$ & \\
\hline 4. & $\begin{array}{l}\text { The minimum requirement for an } \\
\text { innovation is that the product, process, } \\
\text { marketing method or organizational } \\
\text { method must be new (or significantly } \\
\text { improved) to the firm. }\end{array}$ & \\
\hline No & Innovation activities & \\
\hline 1 & $\begin{array}{l}\text { are all scientific, technological, } \\
\text { organizational, financial and } \\
\text { commercial steps which actually, or } \\
\text { are intended to, lead to the } \\
\text { implementation of innovations. } \\
\text { Innovation activities also include R\&D } \\
\text { that is not directly related to the } \\
\text { development of a specific innovation. }\end{array}$ & \\
\hline No & Types of innovation & \\
\hline 1 & $\begin{array}{l}\text { A product innovation is the } \\
\text { introduction of a good or service that is } \\
\text { new or significantly improved with } \\
\text { respect to its characteristics or } \\
\text { intended uses. This includes significant } \\
\text { improvements in technical } \\
\text { specifications, components and } \\
\text { materials, incorporated software, user } \\
\text { friendliness or other functional } \\
\text { characteristics. Product innovations } \\
\text { can utilize new knowledge or } \\
\text { technologies, or can be based on new } \\
\text { uses or combinations of existing } \\
\text { knowledge or technologies. }\end{array}$ & \\
\hline
\end{tabular}


Vol. 10, No. 1, 2021, E-ISSN: 2226-6348 @ 2021 HRMARS

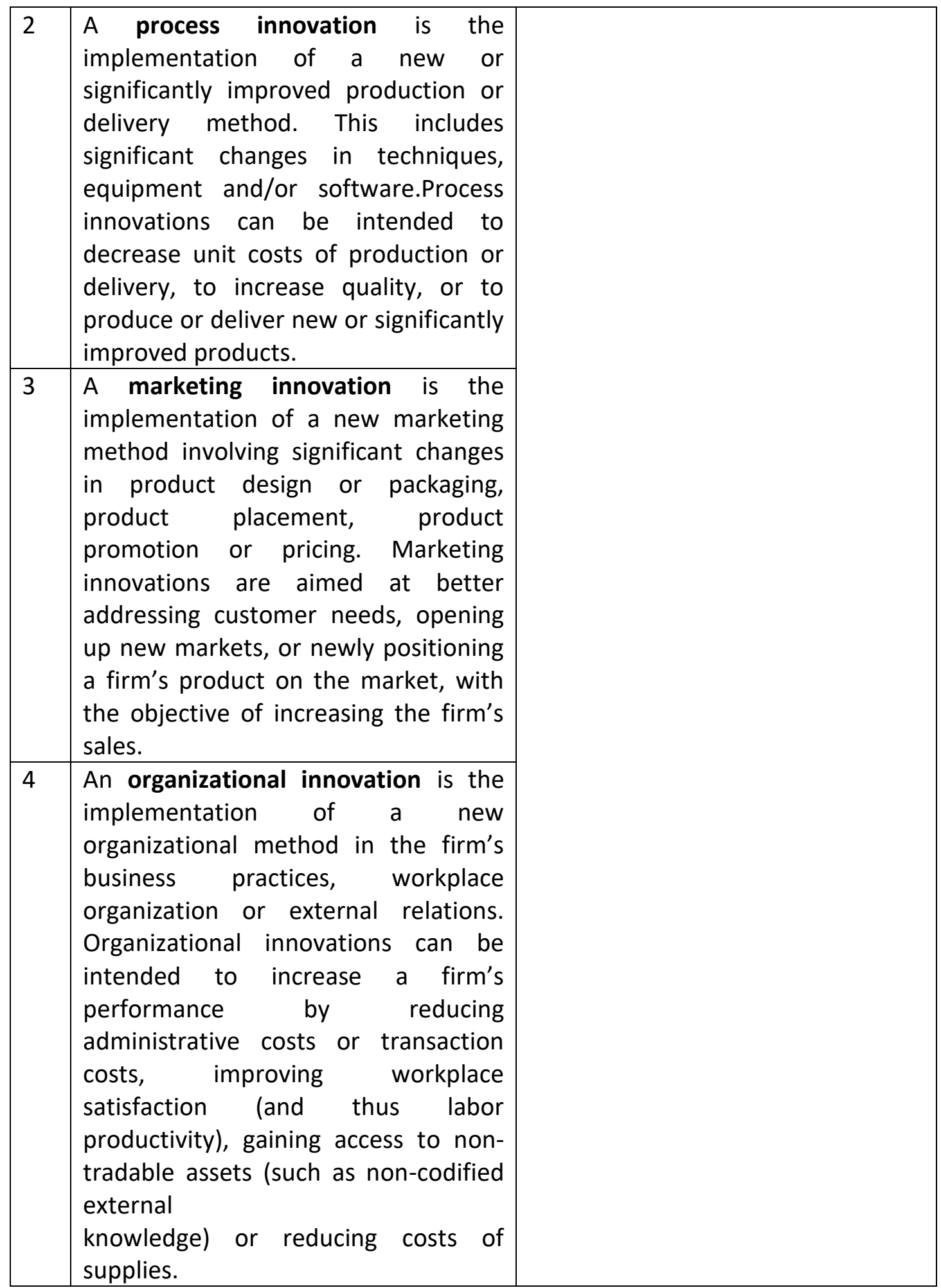

Source: (Oslo Manual, 2005)

Looking carefully, in the Education sector, this open innovation also provides a new strategy or picture in a school. The World of Education has previously relied on knowledge 
activities involving a wide range of Education information, collaboration activities and outsourcing activities. For example, it only involves activities within the school itself that involve teachers, students and the administration of the school itself. Furthermore, external party involvement is neither encouraged nor fully existent. Thus, school performance also involves only the interior of the school and the school network is not fully expanded to enhance the knowledge of the teachers, to enhance the skills and expertise of the teacher and to achieve outstanding school performance.

The unprecedented changes in the education landscape caused by technological advancements and widespread access to information have increased the need for innovation in learning institutions. Avshenyuk (2018) observed that the education sector has significantly benefited from the innovation theory because of its participatory and decentralized approach that promotes various stakeholders' engagement and enhances transparency and cooperation. According to Henry Chesbrough, the open innovation theory is based on the concept of sharing widely distributed information to bridge the gap between business and education (Chesbrough, 2019). Most learning institutions rely on public funds for financial sustainability, which often exposes them to external risks and threats. Mitigating the educational challenges such as limited economic resources and bankruptcy requires significant contributions of the private, the public sector, and strategic management through open innovation (Barham et al., 2020).

The innovation theory helps empower teachers and students because of its participatory approach that enhances learning institutions' knowledge and cultures. Education is a fundamental social institution necessary for the survival and sustainability of society. There is an essential need for educational institutions to continuously evolve to effectively respond to the unprecedented changes and challenges in its external environment (Santoro et al., 2019). Innovation is one-way learning institutions can adapt and cope with the changes in the education landscape. Bogers et al., (2019) found that the innovation theory offers concepts like a collaboration that allows for partnerships and participation of all education stakeholders, including teachers, researchers, students, policymakers, and administrators, in developing effective teaching and learning practices. Participatory innovation leads to the scalable and systemic evolution of the education sector. The innovation theory can also increase the education sector's efficiency and effectiveness by optimizing the available internal and external resources. The internal pressures that drive innovation in education are the growing demand for improving students' quality of learning outcomes. The education sector also faces external pressures from economic, political, and technological factors that present both opportunities and risks for learning institutions (Yun et al., 2020). Many people agree on the need to renew the education system to include more innovative practices and procedures. The open innovation framework combines the internal and external aspects or influences of an institution to drive innovation in education. Its external approach takes the ideas and technologies from outside the institutions to innovate within the education system, according to Odumosu et al., (2020). The internal aspect allows other innovation processes to use under-utilized technologies and ideas from an institution. Innovation theory purposively uses outflows and inflows of knowledge to drive internal educational innovation. 


\section{Resource -Based View Theory (RBV)}

This Resource - Based View Theory has been practiced by various business organizations for the effective performance of an organization (Don-serge et al, 2019). Through this model, many researchers have introduced it as a new business strategy. It has been done by prioritizing resources and it is appropriately managed as it consists of resources, skills, sources of expertise, sources of expertise. Finally, it is fully explored to overcome existing business competition. from time to time. In addition, it has given the business world a new perspective on expanding the performance of their business. Further, has given the organization new perspective on the management of their resources. At the same time, through this model it can be seen that the source of a business's wealth can be expanded from engagement and support from external parties rather than relying on involvement and support from its own organization.

Looking closely, this theory also provides relevant strategies for using resources efficiently and effectively to improve performance in a school. The World of Education was once more dependent on the resources within the organization than on the external resources. In addition, the available resources will increase competition by exploiting them completely instead of the opposite. In addition, each school has its own resources and it represents the specialty of the knowledge, skills, and expertise available to teachers and students.

In this modern age, competition is a common challenge both in the business world and in the Education world. Every organization needs to compete to grow in the long run. Therefore, all the resources, expertise and knowledge resources available in one school must be managed efficiently to ensure healthy competition among other schools in the future. On the other hand, all these sources of resources need to be expanded with the involvement of the other party for mutual benefit.

\section{Resource-Based View Theory in Education}

Delivery of quality education requires the effective utilization of resources, including financial, material, human, and technological. Many learning institutions in Malaysia face challenges due to resource constraints and reduction in government funding (Nagano, 2020). The education sector has increasingly become vulnerable external threats such as lack of funds resulting in reduced competency and low performance. The education sector must now look for ways to adapt to the unprecedented changes and respond to learning institutions' threats and opportunities (Barham et al, 2020). Stakeholders in the education sector have implemented various managerial frameworks, including the resource-based view (RBV), as a coping strategy in unprecedented times (Garland, 2019). This discussion explores how learning institutions can apply a resource-based view for sustainable competitive advantages in the changing education landscape.

Learning institutions always compete against one another for highly qualified staff, government funding, and student enrolments. A resource-based view can help institutions establish and review their competitive advantage strategies because it allows them to identify internal resources to utilize to give them a competitive edge over their competitors. Every institution, including high schools, universities, and colleges, has internal organizational resources to leverage to achieve its goals and objectives (Biwott \& Kimwolo, 2020). Learning institutions always seek, acquire, and utilize resources in various ways, for instance, when hiring 
teachers to deliver services to the students. Institutions that can identify their unique, valuable, and non-substitutable resources, such as their teaching culture, can achieve sustainable competitive advantage because it relies on its internal strengths. It is also essential to note that internal resources vary in different learning institutions. For instance, students' ratio to teachers can differ from one school to another. According to Lingaswaran et al., (2019), the resourcebased view allows institutions to look beyond the sizes or quantity of resources in an institution to the quality and nature of their resources required to achieve a competitive advantage. Institutions that can strategically plan for their unique and valuable resources can effectively respond to the education landscape's disruptions and threats for survival and success. On the other hand, Don-Serge maintains that weaker internal resources can hinder a learning institution's progress because it makes it difficult to respond to education threats or opportunities. He adds that institutions that develop their management strategies based on the resource-based view framework have the internal capacity to respond to the opportunities in its external environment and handle any threats which will ensure their survival and success (DonSerge, 2019).

\section{Independent Variable \\ Knowledge Acquisition}

According to Vega-Encabo (2016), knowledge helps individuals, groups and societies gain a variety of experiences and gain the basic understanding needed to create and maintain environmental sustainability. Hence, knowledge that is managed properly will bring about positive impact to school. This is because, the determinants of an organization's success in managing information must be based on intellectual capital which includes competition for human capital, structured capital and communication capital (Gonzalez \& Martins, 2017). Haradhan (2017), explains knowledge management can be understood when discussing in-depth knowledge of 'tacit' and 'explicit' knowledge. Both of these forms of knowledge are fundamental knowledge of the human body that is useful when information can be shared to work in a team (Breznik, 2017). Knowledge is the basis of effective school management system.

\section{Outsourcing}

Effective schools are schools that emphasize excellence in academic achievement, mastery of basic skills, effective teacher teaching, school climate that can stimulate learning, reduce students' problems and sustainable leadership. The hallmark of effective schools is to have a safe school environment (Burusic et al, 2016), where their students are free from any disturbance or danger to the environment. Effective schools also have mission and school goals that clearly involve all staff in carrying out their duties and responsibilities (Burusic et al. 2016).

\section{Collaboration}

School is a social institution that provides students with knowledge. Excellent and effective schools are led by administrators and teachers who are ready to make changes to achieve their mission and vision. Schools that adopt a collaborative culture are said to have healthy organizational features, including a willingness to change and to be more responsive to change. In fact, any collaborative culture-based work activity is considered one of the ways teachers 
nurture their pedagogical practices together as it improves teacher teaching and learning practices (Tan et al, 2016) and can enhance teacher work motivation (Faiz et al., 2016). Collaboration is not just about working together but about working together toward a common goal that no individual or organization can achieve (Norshidah et al., 2016).

\section{Dependent Variable}

Performance is an important indicator of the results obtained during education. Performance can be interpreted as the outcome or achievement of doing something. In the industrial field, performance is related to the stage of ability of a worker to perform his work function (Sanyal \& Hisam, 2018). In the context of educational psychology, performance is defined as the specific level of a specific skill or ability possessed by students such as arithmetic and reading skills (Turk, 2016). According to Hasbay and Altindag (2018), performance is behaviour-oriented tasks that allow individual achievement to be evaluated according to pre-determined criteria and involving individuals' competency as compared to others.

Proposed Conceptual Framework of the Study

Independent Variable

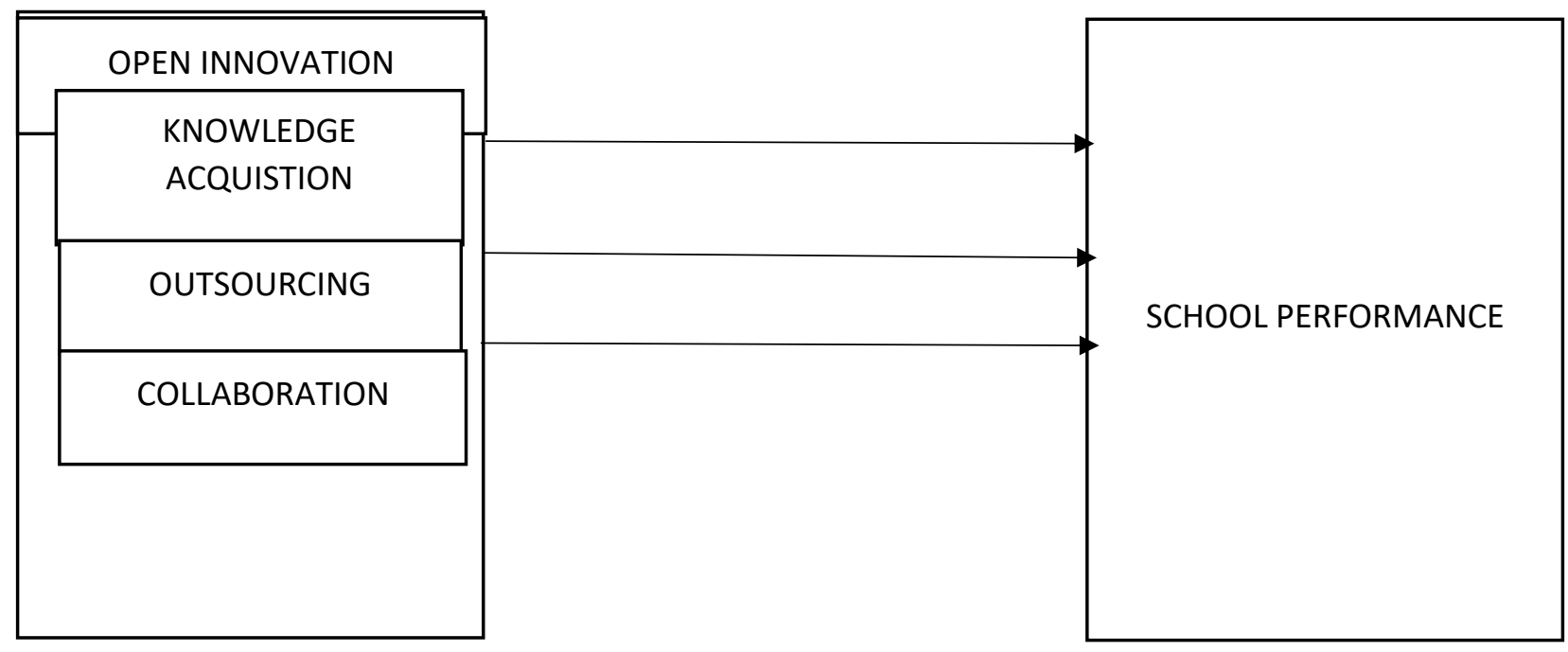

Figure 2: Conceptual Framework Open Innovation in School Environment

This is the new framework which researcher using in this study. In this framework, there are three independent variables. These independent variables are from open innovation such as knowledge acquisition, outsourcing and collaboration. In addition, dependent variable is school performance. Here, researcher will find out the significant relationship between knowledge acquisition, outsourcing and collaboration with school performance. These significant relationship between independent variables and dependent variable and the dependent variable elaborated further in literature review. 


\section{Conclusion}

From the results of the study conducted on the Open Innovation model and RBV theory, new conceptual model was developed to fill the gap of the open innovation context in the Education sector in this study. Literature review on both these theories and models can help the framework that can be applied in schools. Furthermore, through the RBV Theory and the Open innovation model there is a matter of utilization of resources globally. With this, Independent variables have been built with open innovation activities consisting of Knowledge acquisition, collaboration and outsourcing. Therefore, the school management can adapt this kind of activity in the school in the future. In general, the open innovation model emphasizes performance related to quality. It is also equivalent to the theory of RBV. From these two elements a dependent variable was constructed in this study.

\section{References}

Avshenyuk, N. (2018). USA education policy in transnationalization of higher education. Comparative Professional Pedagogy, 8(1), 7-12.

Barham, H., Dabic, M., Daim, T., \& Shifrer, D. (2020). The role of management support for the implementation of open innovation practices in firms. Technology in Society, 63, 101282.

Becker, B. A., \& Eube, C. (2018). Open innovation concept: integrating universities and business in digital age. Journal of Open Innovation: Technology, Market, and Complexity, 4(1), 12.

Biwott, M., \& Kimwolo, A. K. (2020). A resource-based view of curriculum implementation: evidence from primary schools in Marakwet West, Egeiyo Marakwet County, Kenya. Journal of Human Resource \& Leadership, 4(2), 1-13.

Bogers, M., Chesbrough, H., \& Moedas, C. (2018). Open innovation: research, practices, and policies. California management review, 60(2), 5-16.

Bogers, M., Chesbrough, H., Heaton, S., \& Teece, D. J. (2019). Strategic management of open innovation: a dynamic capabilities perspective. California Management Review, 62(1), 7794.

Bratton, J., and Boak, G. (2020). "Strategic Management, Innovation and Leadership." Organizational Leadership: 35.

Breznik, K. (2017). Knowledge management - from its inception to the innovation linkage. Elsevier Procedia- Social and Behavioral Sciences, 238(2018), 141- 148.

Burusic, J., Babarovic, T., \& Velic, M. S. (2016). School effectiveness: An overview of conceptual, methodological and empirical foundations. In school effectiveness and educational management. Springer International Publishing.

Chesbrough, H. (2019). Open innovation results: Going beyond the hype and getting down to business. Oxford University Press.

Couckuyt, D., \& Van Looy, A. (2019). Green BPM as a business-oriented discipline: a systematic mapping study and research agenda. Sustainability, 11(15), 4200.

Don-Serge, H. M. O. (2019). The role of knowledge creation, sharing, and utilization of the resource-based view of competitive advantage. Global Journal of Management and Business Research.

Edwards-Schachter, M. (2018). The nature and variety of innovation. International Journal of Innovation Studies, 2(2018), 65-79. 
Ferraris, A., Santoro, G., \& Papa, A. (2018). The cities of the future: hybrid alliances for open innovation projects. Futures, 103, 51-60.

Garland, M. (2019). Antecedents and outcomes of income diversification in higher education: A resource-based view (Unpublished Doctoral dissertation) University of Gloucestershire.

Gonzalez, R. V. D., \& Martins, M. F. (2017). Knowledge Management Process: a theoreticalconceptual research. Gestão \& Produção, 24(2), 248-265.

Haradham, K. M. (2017). The roles of knowledge management for the development of organizations. Journal of Scientific Achievements, 2(2), 1-27.

Horn, M. B. (2020). Children can be their own teachers: disruptive innovation in education. Childhood Education. 96(1), 24-33.

Iglesias-Sánchez, P. P., Jambrino-Maldonado, C., \& De Las Heras-Pedrosa, C. (2019). Training entrepreneurial competences with open innovation paradigm in higher education. Sustainability, 11(17), 4689.

Jennex, M., Smolnik, S., \& Croasdell, D. (2020, January). Introduction to the Minitrack on Value, Success and Performance Measurements of Knowledge, Innovation and Entrepreneurial Systems. Proceedings of the 53rd Hawaii International Conference on System Sciences.

Jugend, D., Jabbour, C. J. C., Scaliza, J. A. A., Rocha, R. S., Junior, J. A. G., Latan, H., \& Salgado, M. H. (2018). Relationships among open innovation, innovative performance, government support and firm size: Comparing Brazilian firms embracing different levels of radicalism in innovation. Technovation, 74, 54-65.

Linaker, J., Munir, H., Wnuk, K., \& Mols, C. E. (2018). Motivating the contributions: An open innovation perspective on what to share as open-source software. Journal of Systems and Software, 135, 17-36.

Lingaswaran, A., Arjunan, L., Bin Habidin, N. F., \& Bin, M. S. (2019). Safety practices evaluation conceptual model for Malaysian public universities. International Journal of Academic Research in Business and Social Sciences, 9(5).

Mamonov, S., and Peterson, R. (2020). The role of IT in innovation at the organizational level-a literature review. Proceedings of the 53rd Hawaii International Conference on System Sciences.

Nagano, H. (2020). The growth of knowledge through the resource-based view. Management Decision. Management Decision. 58(1):98-111

Saleh, M. N., Ali, M., Abd Majid, R., \& Zainal, K. (2016). Kolaborasi universiti, sekolah dan komuniti menerusi pembelajaran tindakan dan jaringan. ASEAN Comparative Education Research Network Conference, November 30th - December 01st 2016.

Nylund, P. A., Xavier, F. H., \& Brem, A. (2020). Automating profitably together: Is there an impact of open innovation and automation on firm turnover?. Review of Managerial Science 14(1), 269-285.

Odumosu, A. A., Binuyo, A. O., Adefulu, A. D., \& Asikhia, O. U. (2020). Social innovation and graduate entrepreneurship in Nigeria. IOSR Journal of Business and Management (IOSRJBM), 22(2), 48-55.

Oyekan, O. A., Olowu, R. T., \& Awolalu, O. (2020). Research and Innovation in Education: A Case for Inclusion of Global Perspectives for Effective Learning in Formal Education in Ondo, 
Nigeria, in the Twenty-first Century. The Bloomsbury Handbook of Global Education and Learning (369-382).

Osma, J. I. P., Salazar, F. L. M., \& Gomez, K. N. M. (2020). Knowledge management and Industry 4.0 and open innovation. Ingenieria Solidaria, 16(2).

Sanders, J. S., \& Wong, T. (2020). International partner selection among higher education institutions in Hong Kong, Singapore, and Japan: a resource-based view. Journal of Higher Education Policy and Management, 1-16.

Santoro, G., Ferraris, A., \& Winteler, D. J. (2019). Open innovation practices and related internal dynamics: case studies of Italian ICT SMEs. EuroMed Journal of Business.

Secundo, G., Toma, A., Schiuma, G., \& Passiante, G. (2019). Knowledge transfer in open innovation. Business Process Management Journal.

Tan, A. L., Ooi, S. Y., \& Teh, H. L. (2016). Study: Amalan Berkolaborasi Untuk Pembelajaran Berkesan Di Institut Pendidikan Guru: Proceeding of International Consortium of Education and Culture Research Studies (21-30)

Tiwari, R., \& Buse, S. (2020) Key issues in managing innovation in a global and digital world: An introduction to the Festschrift in honor of Cornelius Herstatt. In: Tiwari R., Buse S. (eds) Managing Innovation in a Global and Digital World. Springer Gabler, Wiesbaden. https://doi.org/10.1007/978-3-658-27241-8_1

Vanhaverbeke, W., Roijakkers, N., Usman, M., \& Frattini, F. (Eds.). (2018). Researching open innovation in SMEs. World Scientific.

Vega, E. J. (2016). The concept of knowledge: What is it for? Disputatio. 43(187- 202).

Yun, J. J., \& Liu, Z. (2019). Micro- and Macro-Dynamics of Open Innovation with a QuadrupleHelix Model. Sustainability, 11(12), 3301. doi:10.3390/su11123301

Yun, J. J., Jung, K., \& Yigitcanlar, T. (2018). Open innovation of James Watt and Steve Jobs: Insights for sustainability of economic growth. Sustainability. 10(5): 1-16

Yun, J. J., Zhao, X., Jung, K., \& Yigitcanlar, T. (2020). The culture for open innovation dynamics. Sustainability. 12(2). 5076 